\title{
Micro-hydraulic energy system for electric power production and DSM in buildings
}

\author{
J.C. Sáenz-Díez Muro , J.M. Blanco Barrero ${ }^{1}$, E. Jiménez Macías ${ }^{1}$ and M. Pérez de la Parte \\ ${ }^{1}$ Department of Electrical Engineering. 2 Department of Mechanical Engineering \\ E.T.S.I.I., University of La Rioja. Luis de Ulloa, 20. 26004. Logroño (Spain) \\ Phone/Fax number: +34 941 299502, +34 941 299478, , \\ e-mail \{juan-carlos.saenz-diez; juan-manuel.blanco; emilio.jimenez\}@unirioja.es
}

\begin{abstract}
In this article a procedure of electric power obtaining is presented, based on the micro-hydraulic application derived from the supply pressure of water in the cities; this constitute a step more toward the objective of sustainable buildings (energy and environmentally speaking), and is integrated into the generat electrical power management in biuldings with the main renewable energy systems for electrical supply (basicaly wind and solar energy). The proposed system can be more important in non-developed countries, where the electric supply is not totally reliable, and the water supply of the buildings is made by using water tanks on the top.
\end{abstract}

\section{Key words}

Renewable energy, Sustainable Building, Hydroelectric Energy.

\section{Introduction}

The way toward sustainability like new and essential paradigm of our society drives to the search of the reduction of the energy consumption and the increase of the energy efficiency in our buildings, in combination with the substitution of fossil energy for renewable energy.

Our group has devoted a great effort to contribute to energy efficiency in buildings, based on the use of the resources, and not only keeping in mind the production but especially the contamination that takes place. We have worked in strategies of DSM in buildings, with renewable resources, especially solar and mini-wind energies.

As a step more in that line, a system to use microhydraulics energy to produce electric power in buildings is presented, taking advantage of the high pressure to which the running water is given to buildings in order to assure that it arrives to the housings with more unfavorable conditions (essentially higher altitude level).

The final objective, as much of the mentioned previous works as of the work here presented, is to advance toward the concept of sustainable building, as an important pillar for the global sustainability of the society.

\section{Description of the system}

Buildings feed of drinkable water from the public distribution net. To guarantee the feeding to all the buildings of the city, this net is pressurized with enough pressure so that the most unfavorable buildings (the highest and those located in the highest topographical altitude levels) can be supplied.

For this reason in many of the supplies, advantage can be taken from this differential of pressure, not necessary to supply to the buildings that are not under less favorable conditions (which are majority), for hydraulic use with the goal of electric power production.

It is necessary simply to equip the building with a micro turbine that takes advantage of this differential of pressure, which activates an electric generator. About that basic idea some technical that allow the optimization of the use are added such as the use of DSM strategies in combination with the rest of renewable energy systems, or the construction of a regulation deposit that feeds to the building of drinkable water, to optimize the microhydraulic generation.

All the dispositions that can be given in the hydroelectric power stations offer different variants of develop the use of the hydrological energy. Figure 1 summarize in a graphic way where can be adopted every solution. 


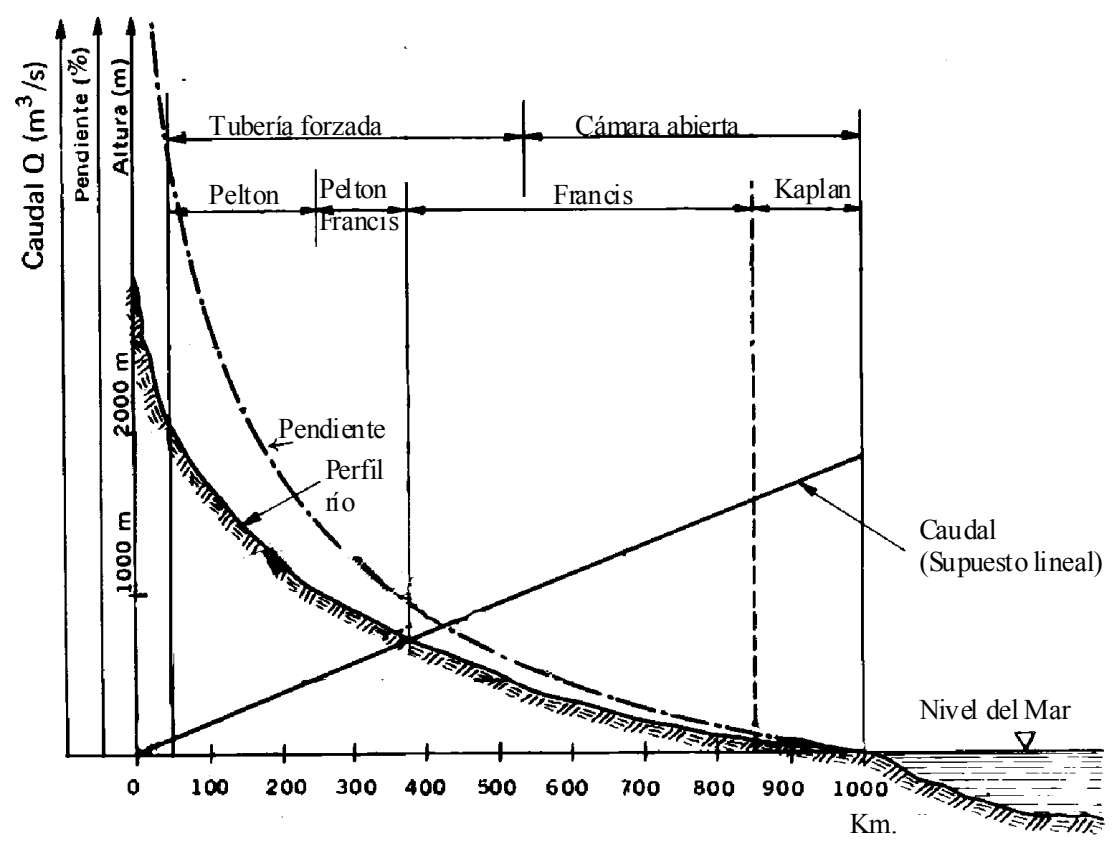

Fig. 1. Different dispositions of the hydrologic system

The maximum theoretical power that can supply a hydrologic system depends on the heigth difference and on the volume of flow through the turbine:

$$
P=Q \cdot \rho \cdot g \cdot H
$$

Where:

$$
\begin{aligned}
& \mathrm{P}: \text { Power }(\mathrm{W}) \\
& \mathrm{H}: \text { Waterfall heigth }(\mathrm{m}) \\
& \mathrm{Q}: \text { volume of flow through the turbine }\left(\mathrm{m}^{3} / \mathrm{s}\right) \\
& \mathrm{g}: \text { gravity }\left(\mathrm{m} / \mathrm{s}^{2}\right) \\
& \rho: \text { Water density }\left(1000 \mathrm{~kg} / \mathrm{m}^{3}\right)
\end{aligned}
$$

In practice this theoretical maximum power calculated decreases due to losses that take place in the different elements of the hydroelectric system. The most important losses occurs in the turbine, in the joining of the turbine with the generator and in the generator.

Less importance presents usually the losses in the connection wires of the generator with the electric net. All those losses can be quantified in order to estimate the global performance rate. This performance rate will be the product of the rates derived from the losses mentioned previously. The global rate can oscillate from 0,5 to 0,75 .

In the proposed system, the flow is variable depending on the necessities of supply of the building, while the waterfall height stays practically constant in a maximum value (regulation to constant height), obtaining the maximum power for every flow value.

The correct design of these two parameters is a fundamental point for the good operation of the installations, as well as to work with appropriate performance rates.

The net waterfall is the height that the turbine can use, and it is similar to the difference of total heights between the input and the output of the turbine.

From Bernoulli's equation, the net waterfall power can be evaluated for the different types of turbines and hydraulic installations.

According to the flow and heigth values, action or reaction turbines can be selected. In the system tha has been developed in this work, practically in all the cases action turbines are more suitable, as can be appreciated in Figure 2. 


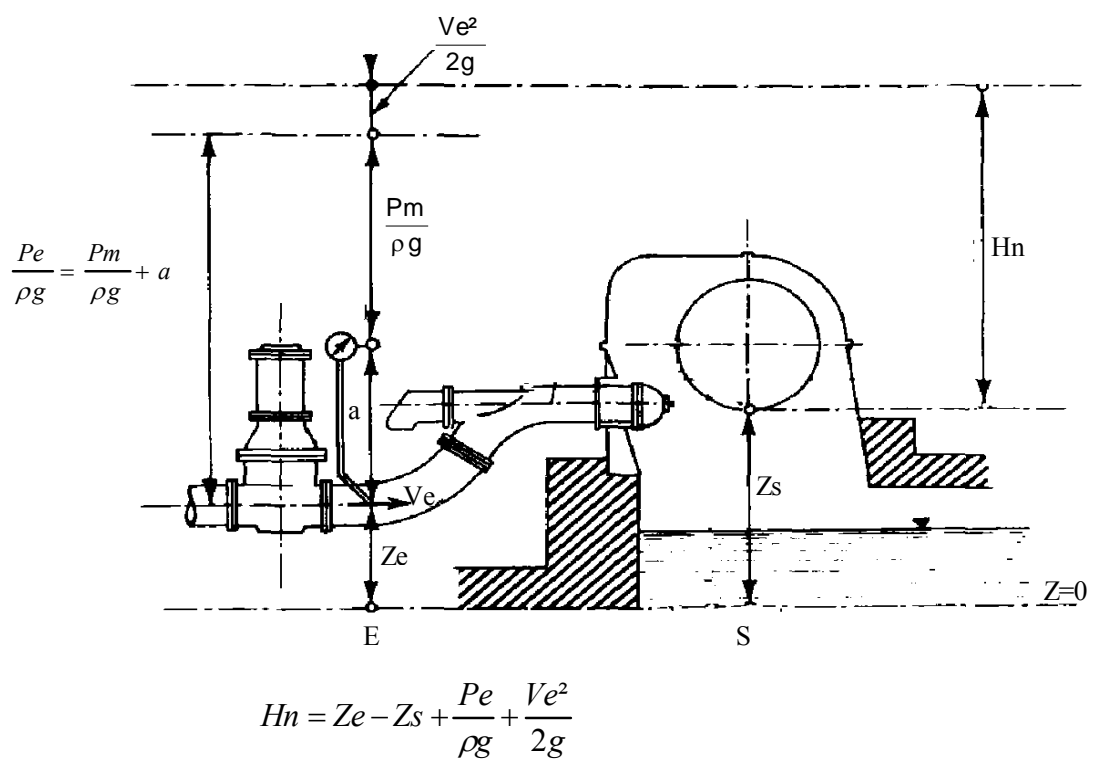

Fig. 2. Action turbine

Particularizing the Figure 2, for the case of the building that is been dealing with, Figure 3 is obtained.

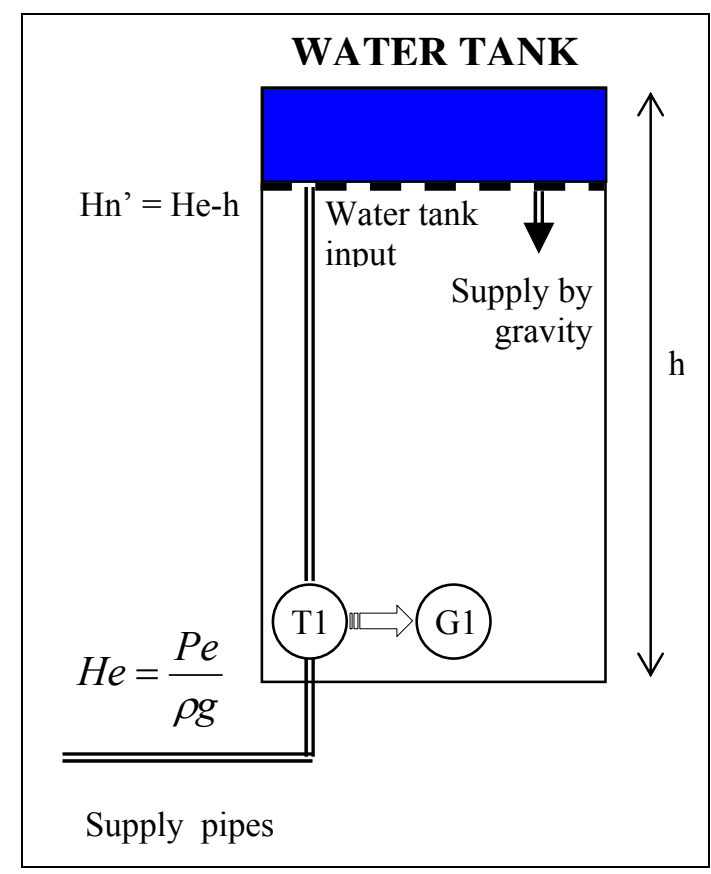

Fig3. hydraulic diagram of the building

\section{Description of the systems of optimization, supervision, control and management}

Algorithms of optimization, supervision, control and management of the system are also taken into account, and implemented in PC by means of industrial software. The PC is located in the technical room of the building; for small buildings a tactile screen can be provided instead of PC in the control panel.

The communication with the different subsystems, as well as with (digital and/or analogical) inputs and/or outputs that are red/written in any area of the building is carried out by means of a WLAN. The chosen software to implement the application belongs to SIEMENS $\AA$ : WinAC $\AA$, for control and WinCC Flexible ${ }^{\circledR}$, for supervision. In both of them optimization routines are implemented.

\section{Conclusions}

In this article a procedure of electric power obtaining is presented, based on the micro-hydraulic application derived from the supply pressure of water in the cities; this is a step more toward the objective of sustainable buildings (energy and environmentally speaking).

The investigation line is framed into the European $\mathrm{I}+\mathrm{D}+\mathrm{i}$ programs for renewable energy and sustainable constructions, and besides its scientific contribution, the elaboration of intellectual property based on it is been processed (models of utility and patents).

\section{Acknowledgement}

This paper has been partially supported by the project DPI2007-66679 from the Spanish Education and Science Ministry, and by the University of La Rioja. 


\section{References}

[1] J.C. Sáenz-Díez, J.M. Blanco, E. Jiménez, M. Pérez, J.I. Latorre, Optimization of Photovoltaic Solar Electric Power for Renewable Energy Generation and DSM Strategies in Singular Apartment Buildings, EA4EPQ International Conference on Renewable Energies and Power Quality (ICREPQ'06), Palma de Mallorca (2006).

[2] J.C. Sáenz-Díez, J.M. Blanco, A. Antoñanzas, Aplicaciones eléctricas industriales de las energías renovables, 220 pp, Madrid (1999). ISBN: 84-6991181-3.

[3] J.C. Sáenz-Díez, J.M. Blanco, Jornadas Eólicas DERrioja, Energías renovables para particulares, pp. 51-68, Logroño (2001).

[4] J.C. Sáenz-Díez, J.M. Blanco, Técnica Industrial, Optimización de generación de energía minihidroeléctrica para estrategias de DSM y sus aplicaciones en edificaciones singulares. Técnica Industrial. Madrid (2004). ISSN 0040-1838-2004.

[5] J.C. Sáenz-Díez, J.M. Blanco, Jornadas Nacionales de Ingeniería Termodinámica. Optimización de generación de energía minihidroeléctrica para estrategias de DSM y su aplicación en edificios singulares, Logroño (2005).

[6] National Institute of Standards and Techno-logy Gaithersburg, Measured Versus Predicted Photovoltaic Performance, Maryland (2005).

[7] L, Dávila, M, Castro, A, Colmenar, J, Carpio, J. Peire, Situación normativa Española en el tema de conexión a red, IX Congreso Ibérico De Energía Solar, Córdoba (2000) .

[8] S.J. Meléndez García, J. Lloveras Maciá, Tesis Doctoral, La fachada acristalada como productora de energía eléctrica, Barcelona (2003).

[9] A.F. Germán Bueno, J.L. Bernal Agustín, Centrales solares fotovoltaicas como apoyo a las redes de transporte y distribución de energía eléctrica, XII Reunión de Grupos de Investigación en Ingeniería Eléctrica, Córdoba (2002).
[10]B. Chowdhury, Evaluating the value of distributed photovoltaic generation in radial distribution systems, IEEE Transactions on Energy Conversión, Vol II, No3, Sept. 1996.

[11]T. Hoff, D.S. Shugar, The value of grid-support Photovoltaics in reducing distribution system losses, IEEE Transactions on Energy Conversion, Vol X, No3, September (1995).

[12] M.A. Castro Gil, Simulación de centrales de energía solar, Aplicación a la gestión energética, (1998).

[13]F.J. Argul, M.Castro, A.Delgado, A.Colmenar, J.Peire, Edificios Fotovoltaicos Técnicas y Programas de Simulación, Pro-gensa, UNED (2004). ISBN: 8495693-12-7.

[14]E. Jiménez Macías, J.M. Varea Aldama, M. Pérez de la Parte, J. C. Sáenz-Diez Muro, "Modelo de gestión energética inteligente en una vivienda domótica aislada". XXVII Jornadas de Automática del Comité Español de Automática CEA_IFAC, 2006.

[15]E. Jiménez, J.M. Varea, M. Pérez, J. C. Sáenz-Diez, J. Blanco, E. Martínez, F. Sanz, "Implementación de sistema de gestión energética en viviendas aisladas", University of Magdeburgo IV Conferencia Científica Internacional de Ingeniería Mecánica, Simposio de Termoenergética Industrial, Energía Renovable y Medio Ambiente, Vol1, 2006.

[16] J.C. Sáenz-Díez Muro, J.M. Blanco Barrero , E. Jiménez Macías, M. Pérez de la Parte and J.I. Latorre Biel, System of Photovoltaic Solar Electric Power for Buildings: "Solar facade with variation of the $\beta$ angle", International Conference on Renewable Energies and Power Quality (ICREPQ'07), 2007, Seville.

[17] J.M. Blanco Barrero, P. Lara Santillán, J.C. SáenzDíez Muro, E. Jiménez Macías Optimization of the hydrological utilization for hydroelectric power plants of flowing type, International Conference on Renewable Energies and Power Quality (ICREPQ'07), 2007, Seville. 